\title{
Business Environment and Survival of the Tourism Inductry
}

\author{
Ndife, Chinelo Franca \\ Department of Business Administration Federal Polytechnic Oko, Anambra State, Nigeria
}

\begin{abstract}
This study is to determine the impact of environment on business performance with the specific objectives of determining the effects of socio-cultural, political and economic environment on business performance. A sample of 57 respondents was selected from some small tourism businesses in Awka. The ChiSquare test of independence and descriptive statistics were use to analyze the responses. It was observed that political and economic environment have significant impact on business performance while the socio-cultural environment does not have a significant relationship. it is therefore recommended that the government should help entrepreneurs to start new tourism business and protect them to continue the business, the government can stimulate private business development and employment growth by fostering an "enabling economic environment
\end{abstract}

Keyword: business environment, tourism, small business, political environment, socio-economic environment

\section{Introduction}

Small and medium scale businesses form an essential part of any economy and therefore influence by various factors that are either internal or external to the business. The problems that small and medium scale enterprises face in conducting successful business can be categorized as external (or macro) or internal (micro) environments based on their origin.

Alexandiova [1] argues that research has shown that external environment has a strong influence on the effectiveness of entrepreneurial activities. He argued that a very important factor of the business success in business transformation and economic reforms in the transition countries is the overall improvement of business environment. stating that, the business environment also creates chances for successful introduction of new products, market propensity and rapid growth of small and flexible entrepreneurial organizations, even though it has been recognized as a man source of uncertainty,.

Zahra[2] noted that entrepreneurs should be considered as a significant factor of the socio-economic development, solving employment problems providing wider range of consumer products and increasing competiveness and overall propensity. That entrepreneurship is often recognized as a response to some environmental conditions that could hinder or support business success by the nature of the climate they establish.

Successful organizations are those that can fit into the opportunities and constraints inherent in the environment they operate. However, business failures may result from the fact that such businesses were started on unrealistic assumptions, that they lacked vital business relations or that they were unable to organize or mobilize their resources efficiently[3]

Businesses face challenges of social considerations which focus on issues that are specific to their activities and transactions with customers, shareholders, suppliers, employees, etc. other social considerations include protecting the health and safety of the general populations, avoiding harm to the natural environment, developing ethical practices and standards that meets social and cultural norms, at the same time balancing interest of both the business and the society (Rainey, 2008). Political considerations are also of great importance since they have direct impact on the success and functioning of business. Regulatory and Political variations are usually the manifestations of socio- economic conditions and issues. Also customers, business and stake holders are economic considerations which often focus on the direct effects of the exchange of goods and services, economic considerations activities such as hidden costs of transactions and the externalities born by the society.

In these regards, environment of a business is the pattern of all the external and internal conditions and influences that affect its survival, growth and development. Hence, it is important on the corporate strategist to keep abreast with the factors of the business environment [4]. Furthermore, the analysis of business environment is the appraisal and examination of opportunities and threats inherent in the environment. Consequently external analysis examines threats and opportunities that exist in the environment while internal analysis examines strength and weakness within the business. Pulendran, Speed \& Widing[5] argued that the external environment in which organizations operate is complex and constantly changing.

The essence of this study is to find out the environment factors that affect small business in Anambra state. The finding will be useful in planning small business and forecasting the effects of changes on such environment factors, thus reducing business survival. 
The objectives of the study are:

\section{Objectives Of The Study}

i. To determine the effects of socio-cultural environment on small business performance.

ii. To find out the relationship between political environment and small business performance.

iii. To ascertain the effect of infrastructural environment on small business performance.

\section{Research Questions}

The following research questions are of interest

i.What is the effect of the socio-cultural environment on small business performance?

ii. What is the effect of the political environment on small business performance?

iii. What is the effect of infrastructural environment on small business performance?

\section{Research Hypothesis}

1. Ho: socio-cultural environment has no significant effect on small business performance.

2. Ho: There is no significant relationship between the political environment and small business performance.

3. Ho: There is no relationship between the infrastructural environment and small business performance.

\section{Review Of Related Literature}

Small businesses can be a vehicle for economic growth. In the last century, small businesses were both a medium for entrepreneurship and a source of income and employment.

This study employs the theory of economic development as conceived by Schumpeter [6]. Schumpeter emphasized the role of the entrepreneur as a major cause of economic development.

Brown \&Lauder [7] advanced three explanations for the shift toward flexibility and smallness. The first wave is related to Fordist production (Mass production) and deals with fundamental changes in the world economy from the 1940s onwards. Second wave started since 1970 called neo-Fordist management system, which due to the changes relate to the increase in the degree of uncertainty, the intensification of global competition and the growth in market fragmentation. The third wave is Post- Fordist system of management, which deals with changes in the character of system of work, technological progress, and human resource development. Study of these waves show that flexible automation has various effects resulting in a shift from large to smaller firms.

Thurik \& Weneekers [8] argues that the instability of markets in the 1970s resulted in the fall of mass production and promoted flexible specialization. This basic change in the path of technological development led to the occurrence of vast diseconomies of scale. Post Fordist system of management is marked with entrepreneurs. For the business, the main purpose of such attractions is to maximize profit and well being of firm's constituents. The business and the environment gain from each other. This typifies interdependence between business and its environment.

Obiwuru, Oluwalaye and Okwu[4] adopted the SWOT matrix in analyzing and appraising the Nigerian business environment. The SWOT matrix analysis technique combines firms internal and external environment and their factors and this help visualized the analysis of business environment and enhanced understanding of how environmental factors work together, culminating in the synthesis. When a business entity matched internal strengths of its customers, and emphasized that business should act to convert internal weakness into strengths and external threats into opportunities. According to the authors, the external environment consists of a set of conditions and influences outside the business but which shapes the life and continued existence of the business unit and also affects changes in the organization that the business cannot control but only adjust to them. Since strategy formulation is futuristic, it is pertinent for strategic managers to keep abreast with the external environment and align their strategic process with the dynamism of such external factors. They noted that the external environment can be captured with the acronym PESTLE (Political, Economic, Social, Technological, Legal and Ecological) factors.

The elements of the internal environment in Nigeria constitute essentially employees attitude, new which equipment, process strategy, work environment etc which are encapsulated in the strengths and weakness of the business, the organization has control of these because they happen within the organization unlike the external environment[9].

The above listed factors are present in the Nigerian business environment and firms have evolved various strategic management approaches in adjusting to them. Prior to the Nigerian government was directly and significantly involved in business, but programmes have relegated the government more to its expected regulatory role and indirect influence in the Nigerian business environment. Examples are in the business of communication, banking, insurance, transportation and in the past decade, tertiary education. These have opened windows of opportunities to business in Nigeria. However infrastructure (power, roads, water, health and multiple tax system remains serious external environmental challenges in Nigeria. Other threats emanated from 
high cost of capital (that is high interest rate), exchange rate volatility, high rate of inflation, weak domestic currency etc.

Obuwuru, Oluwalaye and Okwu[4], further noted that social safety nets have not been given desired attention in policies and programmes of the government and this poses a threat to business in the country. Again the highly skewed income distribution patterns in which over $70 \%$ of Nigerians has adopted micro and mini units packaging at appropriate price as strategic approach to this threat.

On the technological front, investment has been very minimal in research and development and the process of automation hampered by the near zero public power supply to drive and accelerate simulate inventions, innovation, and competition and engender values for money. Alternative power supply increases the cost of doing business and retards the investment in research and development. For the environmental factors especially those associated with the vagaries of weather condition, effects are been made to control and minimize their adverse effects on the environment and business. On business level some firms switch products in line with weather dictates as strategic approached while on national level, National Emergency Management Agency (NEMA) is in charge with this strategic policy responsibility. However, much has not been achieved in this direction. On the legal factors, most existing laws seem obsolete in the current democratic dispensation [10].

According to Obuwuru, Oluwalaye and Okwu[4], economic environment of a business are such factors as economic growth, interest rates, exchange rates and inflation rates. These factors have major impact on how business operate and make decisions. They noted that interest rates could affect the extent to which a business grows and expand. Exchange rates could affect the cost of exporting goods and supply price of imported goods.

Adeoye [10] argued that economic variables have been complex both in form and impact on the practice of business in Nigeria. Consumers and clients have been showing complex behaviors in both local and international market. The most dramatic change has been exhibited by competitive pressure. He further stated that in the contemporary Nigerian business environment, performance of the Nigerian companies is predicted on factors such as low sales, high cost of production, low capital utilization, lack of foreign exchange to source the needed input, poor power supply and low quality of goods and services.

Ogundele (2005) noted that economic environment is a vital concern to an organization, that the economic environment goes a long way to determine and define opportunities for an organization. This is because an expanding economy provides operational scope for the establishment of new ones. However, a period of recession can bring about failures and probably liquidations of the organization. It is of paramount importance that the management should be able to distinguish between short run phenomena and more fundamental changes in its assessment of overall economy.

Adeoye[10] observed a positive and significant relationship between economic environment and organizational performance and argued that a change in economic environment will have a greater contribution on the organizational operations. He further stated that $93 \%$ significant impact of the economic environment was observed on organizational performance.

The political environment entails the extent and process of government and indirect intervention and influence on business in an economy. Political factors include such areas as tax policy, trade restrictions, tariffs, incentives, other encouragement and political stability. Political factors may also include goods and services which the government want (merit goods) and those that the government does not want to be provided (demerit goods). Furthermore, government has great influence on the health education and infrastructure of a nation. The political environment is viewed via legal framework where organizations operate. This is done through the laws and regulations that guide the operations of the business. He stated that the management of an organization must take cognizance of these constraints, actual and potential, and seek out the implications for the business organization from a legal adviser. A positive and significant impact of the political environment on organizational performance was also observed. [4,10].

Saleem (2012) wrote that social factors are the cultural aspects that include health consciousness, population growth rate, age distribution, career attitude and emphasis on safety nets. Trends of social factors affect demand for a company's products and how the company operates. For example, an ageing population may imply a smaller and less willing workforce (thus increasing the labour cost); government enhanced social insurance scheme may increase demand insurance services in a country.

Dana (2009) wrote that diverse socio-cultural environment forces small business managers to become more sensitive to cross cultural issues in the work place. Furthermore management could be more successful if they are culturally flexible and adaptable, leaving behind the ideology of ethnocentricity, believing their own country value and methods are superior.

The social dimensions or environment of a nation determines the values system of the society which in turns affects the functioning of the business. Socio-cultural factors such a cost structures, customs and conventions, cultural heritage, views towards wealth and income, and scientific methods, respect for seniority, mobility of labour etc have for reaching impact on the business. These factors determine the work culture and 
mobility of labour, workgroups etc. socio-cultural environment determines the code of conduct of business should follow the unethical practice.

\section{Reasearch Design And Methodology}

This study is a survey which elicited the opinions of members of staff of some selected hotels in Awka. The objective of the research is to determine the impact of environment factors on the performance firms in tourism business in Anambra state. Structured questionnaires were used to obtain information from the respondents. The questionnaire has sections comprising of Demographic information of respondents and affect of environmental factors on performance of small business. The environmental factors considered were: political, economic and socio-cultural factors. A convenience sampling method was used to obtain the hotels used while simple random sampling was employed in selecting the sample units from each of the three selected hotels. The responses were analyzed using the chi-square test of independence at $5 \%$ level of significance.

The primary source of data was used for this research. Structured questionnaires as well as guided interview were used to obtain information from the sample units. The population of study was the members of staff of some selected hotels in , Anambra state. The hotels have a total of 70 members of staff. A sample of 57 employees was used.

\section{Result And Discusion Of Findings}

This research was on the impact of environmental factor on performance of small tourism businesses in - The purpose was to determine the impact of various business environmental factors on small business performance. To achieve this, a sample of 57 respondents was drawn for the study.

The result shows that the political and economic environments have significant relationship with business performance. while there is no significant relationship between socio-cultural environment and business performance. It was also observed that the two major private/ individual need for hotel are private travel necessity and official need respectively while the two main group need for hotel are conference, seminars and wedding ceremony respectively.

The relationship that does not exist between socio-cultural environment and business performance may be due to the fact that the hotels are not situated in the interior parts of which happens to be main stay of cultural activities. However the finding is not suppressing since Awka is not known to be a cultural minded city.

Lack of some social amenities like electricity, pipe born water, good roads etc may have resulted in the significant association between economic environment and business performance by increasing caused by bad roads etc. however quick access to finance in the form of loan, micro-credit, and increased government expenditure may be positive contributions to this significant relationship

Although there is no strong law guiding the operations of hotels, one may conclude that the significant relationship that exist between the political environment and business performance may be due to government and political parties activities associated with this democratic dispensation, thus increasing patronage.

\section{Recommendations}

With regards to the finding made in this research, the following recommendation will be of great benefit. the government should help entrepreneurs to start new business and protect them to continue the business since small businesses have a greater role in economic growth. The government can stimulate private business development and employment growth by fostering an "enabling economic environment". This could be in the form of moderate regulations; fair taxation that is feasible and simple for compliance; creation of awareness of business support opportunities; reduction in the level of bureaucracy involved in new business development, particularly with respect to the process of employment creation. Government at all levels should make efforts to improve the infrastructural base of the country especially in the areas of road construction and maintenance, electricity generation and social amenities so in other to reduce cost of doing business. The people of Awka and its environs should work towards improving on their cultural activities and festival so as to attract people from far and near, thus increasing patronage of hotels and improving

\section{Reference}

[1]. Zahra, S. (1999). The changing rules of global competitiveness in the 21st century. Academy of Management Executive, 13(4), 3642

[2]. Yadollah, M. \& Sajady, H (unpublished) A study of factors related to successful and failure of entrepreneurs of small industrial business with emphasis on their level of education and training. available at: http://ssrn.com/abstract $=902045$

[3]. Obiwuru, T.C, Oluwalaye, B.O and Okwu, A.T (2011) External and Internal environments of Business in Nigeria: International Bulletin of Business Administration, Issue 12 (2011)

[4]. Pulendran, S., Speed, R. \& Widing II, R.E. (2000). The antecedents and consequences of market orientation in Australia. Australian Journal of Management, 25(2), 119-140

[5]. Schumpeter, J.A., [1912] 1934. Theorie der wirtschaftlichen Entwicklung, Leipzig, Verlag von Duncker \& Humblot. Third edition translated by R. Opie as The Theory of Economic Development, Cambridge: Harvard University Press 
[6]. Brown, P. \& Lauder, H. (1996) Education, globalisation and economic development, Journal of Education Policy, 11, pp. 1- 25.

[7]. Thurik, R.\& Wennekers, S. (2001). Institutions, entrepreneurship and economic performance. Entrepreneurship Policy for the Future, Swedish Foundation for Small Business Research, 51-87.

[8]. Thompson, A. \& Strickland, A. (1996) Strategic Management: concepts and cases. 9th ed. Chicago: Irwin

[9]. Adeoye, A .O (2012): Impact of External Business environment on Organizational performance in the food and beverage industry in Nigeria. British Journal of Arts and Social Science 0(2): 2012

[10]. Igweze, A.H and Etaga H.O (2011): Statistical Analysis with Excel, Minitab and SPSS. Tualas Publishers, Asaba

[11]. Beck, T (2007): Financing Constraints of SMS'S in developing countries: evidence, determinants and solutions. Journal of International money finance, 31(2) $491-441$

\section{QUESTIONNAIRES}

\section{Section A: Demographic Information}

Please tick $(\sqrt{ })$ as appropriate

1. Age [ ] 20-25 [ ] 26-30 [ ]31-35 [ ]36-40 [ ]40 and Above

2 Gender: [ ] Male [ ] Female

3. Religion: [ ] Christianity [ ] Islam [ ] Others Spacify

4. Marital status: [ ] Single [ ] Married [ ] Divorce [ ] Widow-

5. Work experience (Years) [ ] 0-4yrs. [ ]5-9yrs. [ ]10-14yrs. [ ] 15and above

6. Educational Qualification:[ ] SSCE [ ] OND/NCE[ ] HND / BSC [ ] PGD / MSC

7. Position on Organization

\section{Section B: Impact Of Environment On Business Performance}

8. Which of these is the most encountered reasons for Personal/Private use of Hotels

[ ] Fun \& Relaxation

[ ] Travel Necessity

[ ] Ceremonies/ Occasions

9. which of these is the most encountered group need for Hotels

[ ] Government meeting

[ ]Government functions

[ ] Wedding ceremonies

[ ] Conferences / Seminars

Please Indicate your opinion by ticking appropriate numbers

Scale: 1 = Strongly Disagree; 2= Disagree 3: Undecided 4= Agree;5 = Strongly Agree

\section{Socio -Cultural Environment and small business}

10. Some cultural practices affect business performance

[1] [2] [ 3 ] [ 4 ] [ 5 ]

11. Population Structure affects business performance

[1] [ 2 ] [ 3 ] [ 4 ] [ 5 ]

12. Some cultural/religious believes affect patronage of Hotels

[1] [ 2 ] [ 3 ] [ 4 ] $\quad\left[\begin{array}{l}5 \\ \hline\end{array}\right.$

13. Illiteracy level of the people affects performance of Hotels

[1 ] [ 2 ] [ 3 ] [ 4 ] $\quad\left[\begin{array}{l}5 \\ \hline\end{array}\right.$

\section{Political Environment And Business Performance}

14. Government Laws/Policies affects business performance

[1] [2 ] [ 3 ] [ 4 ] [ 5 ]

15. Government activities/Functions affects business 
[1] [2] [ 3 ] [ 4 ] [ 5]

16. Activities of political Parties affect business performance

[1] [ 2 ] [ 3 ] [ 4 ] [ 5 ]

17. Democracy has a positive impact on business performance

[1] [ 2 ] [ 3 ] [ 4 ] [ 5 ]

\section{Economic Environment And Business Performance}

18. The level of infrastructure affects business performance

[1] [ 2 ] [ 3 ] [ 4 ] [ 5 ]

19. The level of productivity of the people has effect on business performance

[1] [ 2 ] [ 3 ] [ 4 ] [ 5 ]

20. Governments expenditure has effect on business performance

[1 ] [ 2 ] [ 3 ] [ 4 ] $\quad\left[\begin{array}{l}5 \\ \hline\end{array}\right.$

21. Overall economy of the State has effect on business performance

[1] [2] [ 3 ] [ 4 ] [ 5 ] 